\title{
ASSESSMENT OF THE CURRENT STATE OF INFORMATICS AND PROGRAMMING TEACHING FROM THE STUDENTS` POINT OF VIEW
}

\author{
Ján ZÁHOREC - Alena HAŠKOVÁ
}

\begin{abstract}
In their paper the authors present a part of their research results, they obtained within a broader research focused on possibilities to influence students' attitudes and approaches to particular subjects, mainly the less favourite ones. On the background of the obtained results they discuss here students' interest in study informatics and programming and try to identify the reasons of students' interest or disinterest in these subjects. They try to answer the question what are currently the most powerful motivation factors for students to acquire new knowledge from these areas.
\end{abstract}

Key words: teaching subjects, students'attitude towards partial subjects, favourite subjects, natural science subjects, physics, informatics, programming, interest in study informatics and programming, motivation factors

\section{HODNOTENIE STAVU VYUČOVANIA INFORMATIKY A PROGRAMOVANIA Z POHLADU ŠTUDENTOV}

Abstrakt: V príspevku je prezentovaná čast’ výsledkov výskumu, ku ktorým autori dospeli v rámci širšie koncipovaného výskumu zameraného na sledovanie možností ovplyvňovania postojov a vztahov študentov $k$ jednotlivým vyučovacím predmetom, a to hlavne k tým, ktoré patria medzi ich neoblúbené predmety. Na základe získaných výsledkov sa vtomto príspevku zaoberajú problematikou záujmu študentov o štúdium informatiky a programovania a pokúšajú sa identifikovat' príčiny záujmu, resp. nezáujmu študentov o tieto predmety. Snažia sa nájst' odpoved' na otázku, čo sú v súčasnosti najsilnejšie motivačné faktory na podnietenie záujmu študentov o získavanie nových poznatkov z týchto oblastí.

Kl'účové slová: Vyučovacie predmety, vzt’ah študentov kjednotlivým predmetom, oblúbené predmety, prírodovedné predmety, fyzika, informatika, programovanie, záujem o štúdium informatiky a programovania, motivačné faktory

Úvod

Stredné aj vysoké školy na Slovensku ale aj v zahraničí signalizujú klesajúci záujem mládeže o štúdium technického a prírodovedného zamerania. Táto tendencia je spájaná s tvrdením o zvyšujúcej sa ne-oblúbenosti prírodovedných predmetov ako sú fyzika, chémia a matematika. Otázka je ako je to so vzt'ahom študentov $\mathrm{k}$ vyučovacím predmetom informatika a programovanie. Patria u študentov k oblúbeným alebo neoblúbeným predmetom? Je ich štúdium pre študentov zaujímavé a atraktívne? Čo môže na študentov pôsobit' $\mathrm{v}$ tomto smere motivačne? V d'alšom prezentujeme čast' výsledkov širšie zameraného výskumu, ktoré nám môžu poskytnút' odpovede na uvedené otázky.

\section{Východiská výskumu}

V polovici devät'desiatych rokov (1995 1996) V. Šebeň a R. Jakubov uskutočnili prieskum, ktorého ciel'om bolo zistit', k akým zmenám došlo za obdobie desiatych rokov vo vzt'ahu žiakov (ZŠ) k vyučovaciemu predmetu fyzika. Ich prieskum nadväzoval na predchádzajúci výskum V. Šebeňa a M. Mlynára z období rokov 1984 - 1985 zameraný na problematiku zvyšovania záujmu o fyziku a motivácie o jej štúdium (In: Šebeň - Jakubov, s. 71). Z výsledkov výskumu (1984 - 1985) vyplynulo, že na zvýšenie záujmu o fyziku má najväčší vplyv práca s prístrojmi, pomôckami a pokusy. Pokusy pritom pôsobili ako silnejší motivačný faktorom vo vzt’ahu $\mathrm{k}$ chlapcom a slabším žiakom $\mathrm{v}$ porovnaní $\mathrm{s}$ dievčatami, resp. lepšie prospievajúcimi žiakmi. V prípade lepšie prospievajúcich žiakov sa ako silný motivačný faktor prejavovalo už samotné poznávanie, získavanie nových poznatkov, pochopenie učiva a jeho význam pre prax a d’alšie štúdium. Pri výklade nového učiva 
k vytvoreniu záujmu o preberané učivo mala najväčší motivačný účinok motivácia opierajúca sa o skúsenosti žiakov, respektíve vychádzajúca z potreby osvojit' si nové poznatky. Napriek všeobecne akceptovaným proklamáciám o pozitívnom vplyve zarad'ovania problémových úloh do vyučovania na zvyšovanie záujmu o preberané učivo, motivácia nastolovaním problémových situácií sa nepotvrdila. Negatívnym zistením výskumu bolo, že v súvislosti $\mathrm{s}$ fyzikou žiaci trpia obavami, strachom a frustráciou v spojitosti so všetkými druhmi skúšok. Na základe použitia rovnakého výskumného dotazníka ako bol použitý vo výskume realizovanom v rokoch 1984 - 1985, V. Šebeň a R. Jakubov hl'adali odpoved' na otázku, ktoré z motivačných faktorov sú aktuálne prevládajúce pri formovaní kladného vzt'ahu žiakov $\mathrm{k}$ fyzike a ktoré pôsobia negatívne. Výsledky ich komparačného prieskumu $\mathrm{v}$ žiadnom ohl'ade neboli radostné. Ukázalo sa, že za uplynulých desat' rokov (1985 - 1995) oblúbenost' fyziky ako vyučovacieho predmetu sa ešte viac znížila, žiakom sa javí ešte viac nezaujímavá a t’ažká a vel'mi nepríjemným zistením bola skutočnost', že klesol motivačný potenciál prístrojov a pomôcok a pokusy prestali výraznejšie podnecovat' záujem žiakov o fyziku (najmä u dievčat). Naopak pozitívnym zistením bolo, že stúpol záujem o riešenie fyzikálnych úloh a ako efektívna vyučovacia metóda pri výklade nového učiva sa prejavili heuristické rozhovory. V porovnaní s výsledkami predchádzajúceho výskumu klesli obavy žiakov z písomných skúšok, no značne sa zvýšili ich obavy z ústneho skúšania pri tabuli. Tento výsledok však zrejme súvisel so skutočnost'ou, že kým v predchádzajúcom období významným motivačným faktorom pre žiakov bolo nadobudnutie vedomostí a ich využitie v d’alšom štúdiu a praxi, v sledovanom období sa najvýraznejším motivačným činitel'om pre žiakov stalo získanie dobrej známky.

Vytvorenie záujmu o preberané učivo a motivácie $\mathrm{k}$ jeho pochopeniu a osvojeniu si predstavuje základ psychologického zabezpečenia učebného procesu. Toto by malo byt' založené na vytvorení pozitívneho emocionálneho vzt'ahu k preberanej problematike. Emociogénna situácia v regulácii poznávacej činnosti môže byt' založená na rôznych prvkoch. Môžu to byt' prvky sút'aživosti, úspešnosti, prezentácia hudobnopsychologických alebo výtvarno-estetických prvkov alebo zarad'ovanie aktuálne populárnych atraktívnych fenoménov do vyučovacieho procesu. $\mathrm{Z}$ nášho pohl'adu k základným prvkom vytvárania emociogénnych tvorivých učebných situácií prirad'ujeme efekt novosti, populárnosti a atraktívnosti a práve tieto atribúty v súčasnosti ešte stále pre mládež majú nové informačné a komunikačné technológie a multimediálna technika. Pri ich zavádzaní do vyučovania sa zdôrazňuje ich priamy vplyv na zvyšovanie úrovne vzdelávania a zvyšovanie didaktickej efektívnosti foriem a metód vyučovania (napr. Burgerová, 2003). Menšia pozornost' je venovaná možnostiam vzbudzovania záujmu o jednotlivé študijné predmety ich prostredníctvom. Súčasné informačné a komunikačné technológie a multimédiá okrem toho, že vytvárajú prirodzené prostredie existencie dnešnej mládeže, majú pre mládež ešte stále aj určitú fascinačnú silu (čo o d'alších desat' rokov už tiež nemusí platit'). A práve túto ich fascinačnú silu a popularitu u mládeže sme sa pokúsili využit' na zníženie, resp. eliminovanie miery neoblúbenosti určitých predmetov, konkrétne jedného z najneobl'úbenejších predmetov a to predmetu fyzika.

Náš predpoklad, že vyučovanie podporované elektronickými výučbovými prostriedkami prispieva $\mathrm{k}$ znižovaniu negatívnych postojov študentov $\mathrm{k}$ vyučovacím predmetom nebol len čisto intuitívnou záležitost'ou. Jeho oprávnenost' potvrdzujú napr. výsledky výskumu vplyvu informačných technológií a informačných kompetencií učitel'ov na postoje žiakov k vlastnému procesu učenia, ktorý uskutočnili T. Nagy, M. Kubiatko a S. Nagyová (2008, s. 23). Tento výskum bol realizovaný $\mathrm{v}$ dvoch etapách. Prvá bola realizovaná v rokoch 2000 2001 a druhá v roku 2007. V období rokov 2000 - 2001 bola preškolená vzorka 240 učitel'ov z celého Slovenka na zarad'ovanie a využívanie informačných a komunikačných technológií vo vyučovacom procese a následne v roku 2007 sa na vzorke 659 žiakov z tých škôl, z ktorých v predchádzajúcej etape (2000 2001) učitelia absolvovali príslušné preškolenie, sledovali ich postoje a názory k problematike využívania informačných a komunikačných technológií $\mathrm{v}$ procese vzdelávania a ich d'alšom profesionálnom zameraní.

Hlavným zameraním nami realizovaného výskumu bolo, ako sme naznačili, overenie 
možností využívania multimédiami podporovaného vyučovania na elimináciu vysokej miery neoblúbenosti určitých predmetov, pričom sme sa sústredili na fyziku ako výrazne neoblúbený predmet (Záhorec, 2008). Ako východisko celého výskumu sme považovali za potrebné exaktne potvrdit' nízku obl'úbenost', resp. vysokú neobl'úbenost' fyziky. Túto čast' výskumu sme koncipovali širšie a diagnostikovali sme súčasný stav miery oblúbenosti celého základného spektra vyučovacích predmetov a pre každý predmet sme sa snažili identifikovat' možné príčiny jeho oblúbenosti, resp. neobl'úbenosti súvisiace s určitými motivačnými faktormi. Pozrime sa ako v tomto kontexte dopadlo vyučovanie predmetov informatika a programovanie.

\section{Metodika výskumu}

Výskum sme realizovali v období rokov 2007 - 2008 na Gymnáziu Golianova ul. v Nitre. Výskumnú vzorku tvorili študenti 4. ročníka štvorročnej vetvy tohto gymnázia a 8 . ročníka (oktáva) jeho osemročnej vetvy (t.j. študenti vekovej úrovne 17 - 19 rokov). 49 študentov navštevovalo triedu so zameraním na informatiku a programovanie (4.C a oktáva B) a 24 študentov triedu so zameraním na cudzie jazyky (oktáva A). Z celkového počtu študentov zapojených do výskumu bolo $58,5 \%$ chlapcov a $41,5 \%$ dievčat.

Vstupné výskumné údaje sme získali na základe administrovania špeciálne vytvoreného dotazníka Hodnotenie vyučovacích predmetov študentmi zhladiska stanovených faktorov. Svoje postoje (oblúbenost' - neobl'úbenost', pozitívne hodnotenie - negatívne hodnotenie) študenti vyjadrovali prostredníctvom šest' stupňovej škály. Aby sme získali od respondentov ich vyhranené názory, vol'bu neutrálneho postoja sme do škály nezaradili. Jednotlivým stupňom škály boli priradené nasledujúce bodové hodnotenia:

$$
\begin{aligned}
& \text { +3 vel'mi oblúbený } \quad-3 \begin{array}{c}
\text { vel'mi neoblúbený } \\
\text { vel'mi zaujímavé nezaujímavé }
\end{array} \\
& \text { +2 oblúbený } \quad-2 \text { neoblúbený } \\
& +1 \quad \begin{array}{c}
\text { skôr oblúbený } \\
\text { skôr zaujímavé }
\end{array} \quad-1 \quad \begin{array}{c}
\text { skôr neoblúbený } \\
\text { skôr nezaujímavé }
\end{array}
\end{aligned}
$$

$\mathrm{Na}$ ohodnotenie miery oblúbenosti, resp. neoblúbenosti jednotlivých vyučovacích predmetov sme použili štyri veličiny a to globálnu oblúbenost' predmetu, koeficient globálnej oblúbenosti, parciálny koeficient obl'úbenosti

a parciálny

koeficient neoblúbenosti.

Globálna oblúbenost' predmetu predstavuje percento študentov $\mathrm{z}$ celkového počtu respondentov, ktorí deklarovali svoj pozitívny vzt'ah k príslušnému predmetu (t.j. hodnotili ho ako svoj skôr obl'úbený, oblúbený alebo dokonca vel'mi oblúbený). Jej hodnota je definovaná ako súčet počtu študentov s pozitívnym hodnotením príslušného predmetu vydelený celkovým počtom zúčastnených respondentov.

Koeficient globálnej oblúbenosti je vypočítaný ako súčet násobkov bodovej hodnoty príslušného stupňa škály a počtu študentov, ktorí ho uviedli, delený celkovým počtom respondentov.

Parciálny koeficient oblúbenosti je odvádzaný z odpovedí respondentov, ktorí príslušný predmet uvádzali ako svoj oblúbený (t.j. nie z odpovedí celej skupiny respondentov ako je to $\mathrm{v}$ prípade koeficienta globálnej oblúbenosti) a parciálny koeficient neoblúbenosti je odvádzaný z odpovedí respondentov, ktorí príslušný predmet uvádzali ako svoj neobl'úbený. Parciálny koeficient oblúbenosti je teda počítaný ako priemer hodnôt označovaných na zadanej trojstupňovej škále $(+1,+2,+3)$ podskupinou respondentov, ktorí deklarovali svoj pozitívny vzt'ah k príslušnému predmetu a parciálny koeficient neoblúbenosti predmetu je počítaný ako priemer hodnôt označovaných na zadanej trojstupňovej škále $(-1,-2,-3)$ podskupinou respondentov, ktorí deklarovali svoj negatívny vzt'ah k príslušnému predmetu.

Pri analýze motivačných faktorov (zvlášt' vo vzt'ahu ku každému vyučovaciemu predmetu) sme sa zamerali na šest' položiek:

$>$ zaujímavost' obsahu učiva,

$>$ zaujímavost' riešenia úloh,

> spôsob prezentácie učiva učitel'om,

$>$ zaujímavost' učebných pomôcok,

> využitel'nost' poznatkov pre vlastnú budúcnost',

> využitel'nost' poznatkov pri riešení praktických úloh.

Študenti silu jednotlivých faktorov (významnost' príslušného faktora pre ich vlastnú osobu) hodnotili zo svojho pohl'adu prostredníctvom vyššie uvedenej škály. $\mathrm{Na}$ základe ich hodnotení boli pre jednotlivé motivačné faktory odvodené koeficienty celkového (globálneho) hodnotenia, (parciálneho) pozitívneho hodnotenia 
a (parciálneho) negatívneho hodnotenia a to analogickým spôsobom ako v prípade veličín charakterizujúcich oblúbenost' vyučovacích predmetov. Výsledky boli spracované jednak pre skupinu všetkých respondentov, bez ohl'adu na zameranie ich študijnej profilácie, a jednak separátne pre respondentov v závislosti od ich študijného zamerania, t.j. zvlášt' pre skupinu študentov navštevujúcich triedy so zameraním na informatiku a programovanie a zvlášt' pre skupinu študentov s rozšíreným vyučovaním cudzích jazykov.

Výsledky hodnotenia vzt'ahu študentov k vyučovacím predmetom informatika a programovanie

Výsledky analýzy vyhodnotenia vzt’ahu študentov $k$ jednotlivým vyučovacím predmetom uvádzame tabelované pre celý výskumný súbor študentov bez diferenciácie na ich študijné zameranie (Tabul'ka 1). Výsledná hierarchia predmetov podl'a ich globálnej obl'úbenosti u študentov je znázornená na grafe 1. Na porovnanie ako je to s mierou (silou) oblúbenosti jednotlivých predmetov u tých študentov, ktorí k týmto predmetom majú pozitívny vzt'ah, a mierou (silou) neobl'úbenosti toho istého predmetu u študentov, ktorí k nemu majú negatívny vzt'ah, uvádzame výsledky spracované $\mathrm{v}$ grafickej forme na grafe 2 .

Získané výsledky ukazujú všeobecnú tendenciu preferovania spoločenskohumanitných predmetov. Do skupiny najoblúbenejších vyučovacích predmetov patrí Náuka ospoločnosti (NOS) s globálnou oblúbenost’ou 0,85 a cudzí jazyk (CJ), ktorého globálna obl'úbenost' je 0,76 . V súvislosti s celkovým vysokým hodnotením oblúbenosti spoločensko-humanitných vied je určite zarážajúci markantný prepad slovenského jazyka (SJ), ktorý s globálnou oblúbenost'ou 0,45 uzatvára spolu s chémiou a fyzikou rebríček oblúbenosti vyučovacích predmetov. Diskutabilné je, či získané výsledky potvrdzujú alebo nepotvrdzujú tvrdenie o všeobecnej neoblúbenosti prírodovedných disciplín. Za predpokladu, že informatiku a programovanie považujeme za predmety technického charakteru a nie prírodovedného, tak môžeme potvrdit', že prírodovedné predmety sa vyznačujú negatívnym postojom mládeže k nim. Fyzika a chémia získali jednoznačne najnižšie hodnotenia oblúbenosti vyjadrené globálnymi koeficientmi.

\begin{tabular}{|l|c|c|c|c|}
\hline $\begin{array}{c}\text { Skratka } \\
\text { predmetu }\end{array}$ & $\begin{array}{c}\text { Globálna } \\
\text { obl'úbenost' }\end{array}$ & $\begin{array}{c}\text { Koeficient } \\
\text { globálnej } \\
\text { obl'úbenosti }\end{array}$ & $\begin{array}{c}\text { Parciálny } \\
\text { koeficient } \\
\text { obl'úbenosti }\end{array}$ & $\begin{array}{c}\text { Parciálny } \\
\text { koeficient } \\
\text { neobl'úbenosti }\end{array}$ \\
\hline INF & 0,85 & 1,45 & 1,96 & $-1,50$ \\
\hline NOS & 0,82 & 1,29 & 2,21 & $-2,80$ \\
\hline CJ & 0,76 & 1,02 & 1,85 & $-1,55$ \\
\hline TV & 0,76 & 1,02 & 1,98 & $-1,95$ \\
\hline PRO & 0,73 & 0,98 & 2,18 & $-2,20$ \\
\hline EV/NAB & 0,70 & 0,83 & 2,05 & $-1,96$ \\
\hline GE & 0,67 & 0,74 & 1,85 & $-1,52$ \\
\hline DEJ & 0,65 & 0,72 & 2,08 & $-1,76$ \\
\hline M & 0,59 & 0,15 & 1,73 & $-2,09$ \\
\hline BIO & 0,56 & 0,13 & 1,87 & $-2,08$ \\
\hline VV & 0,49 & $-0,15$ & 1,78 & $-1,98$ \\
\hline HV & 0,48 & $-0,18$ & 1,79 & $-1,98$ \\
\hline EST & 0,48 & $-0,27$ & 1,44 & $-1,81$ \\
\hline SJ & 0,45 & $-0,33$ & 0,91 & $-1,76$ \\
\hline CH & 0,28 & $-1,18$ & 1,52 & $-2,24$ \\
\hline F & 0,22 & $-1,32$ & 1,67 & $-2,16$ \\
\hline
\end{tabular}

Tabul'ka 1: Vyhodnotenie oblúbenosti jednotlivých vyučovacích predmetov Legenda k tabul'ke:

INF - informatika, NOS - náuka o spoločnosti, CJ - cudzí jazyk, TV - telesná výchova, PRO programovanie, EV - etická výchova, NAB - náboženstvo, GE - geografia, DEJ - dejepis, M matematika, BIO - biológia, VV - výtvarná výchova, HV - hudobná výchova, EST - estetika, AJ - slovenský jazyk a literatúra, $\mathrm{CH}$ - chémia, F - fyzika 


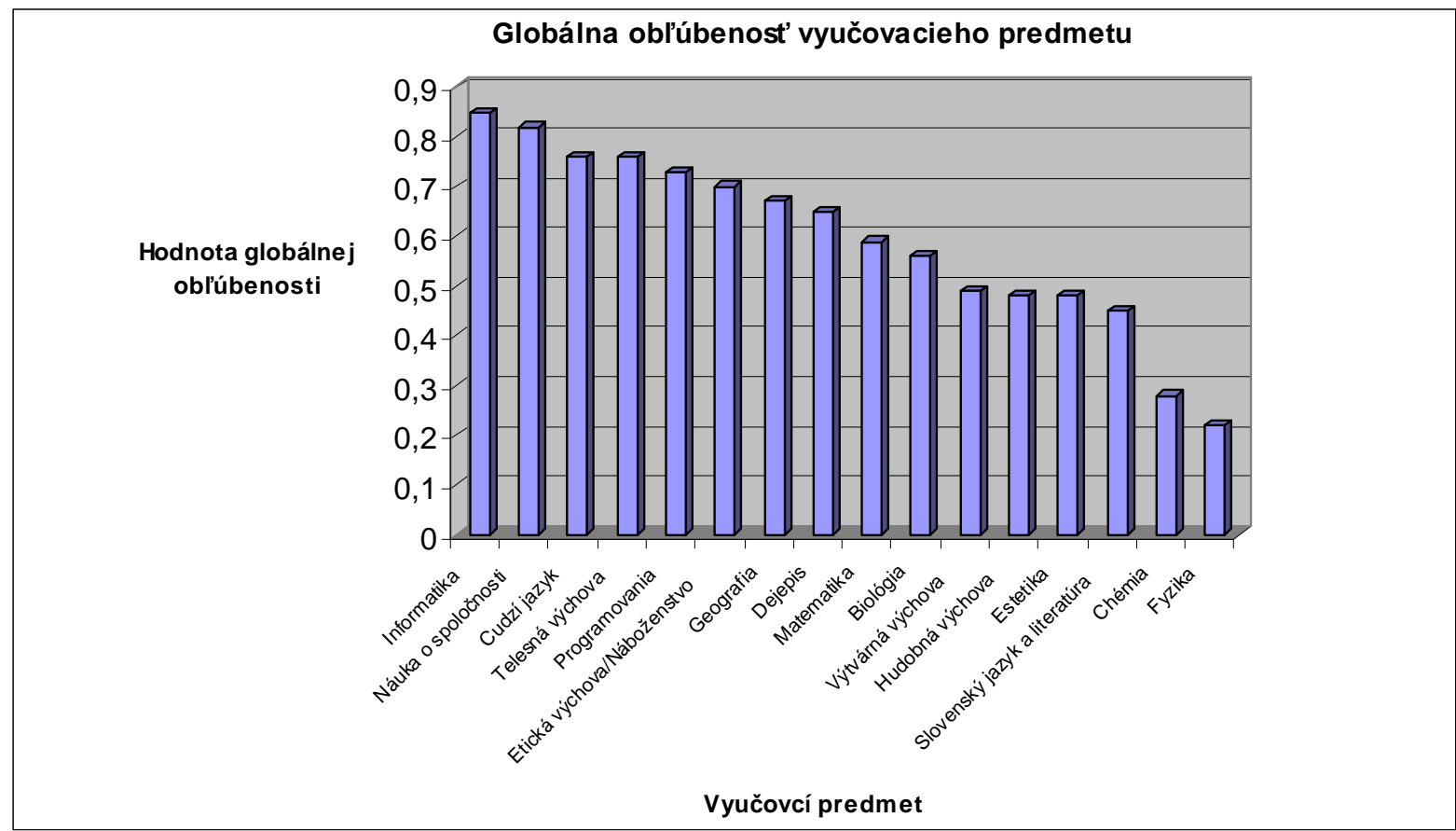

Graf 1: Hierarchické usporiadanie predmetov podl'a ich globálnej obl'úbenosti

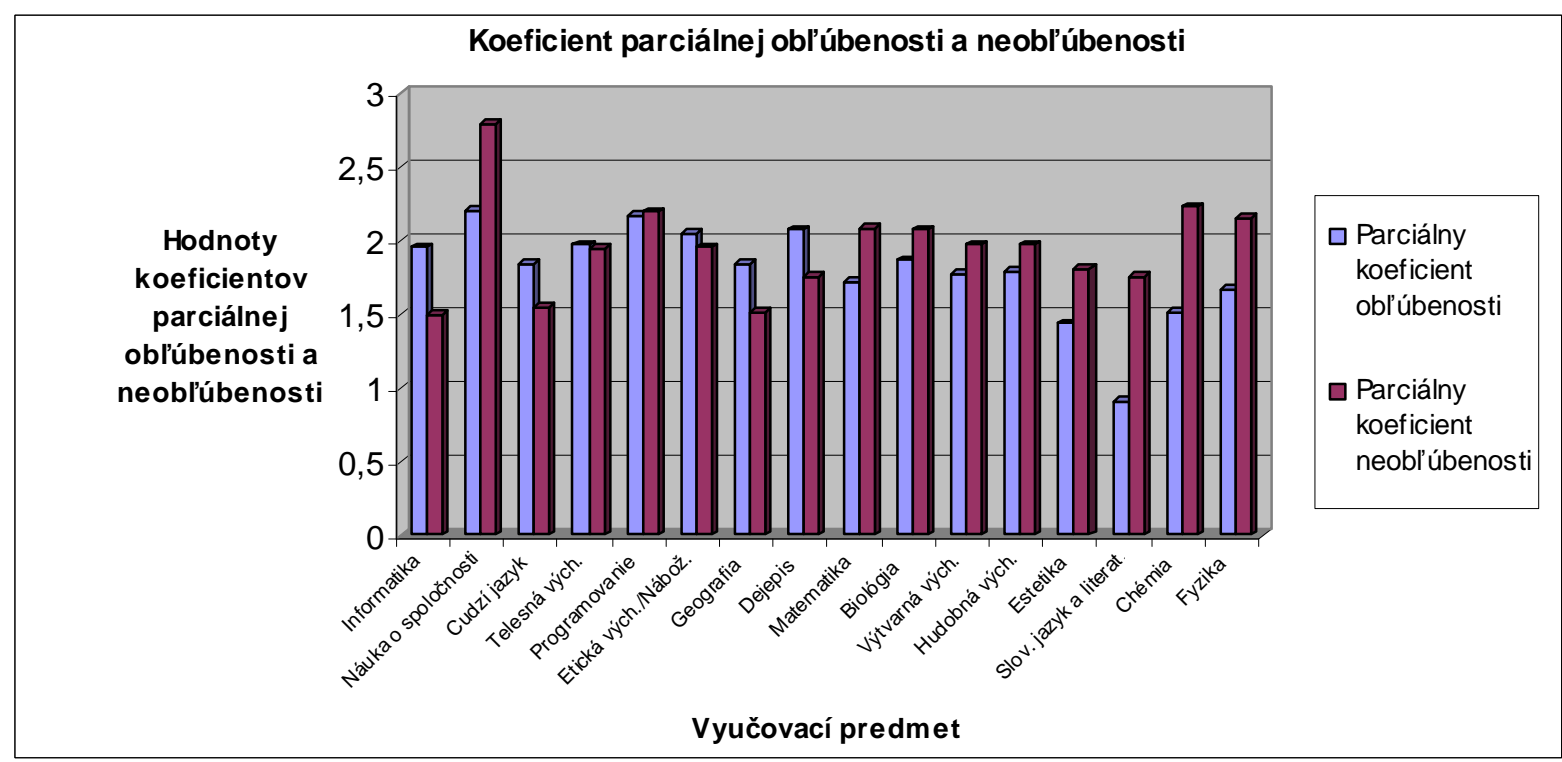

Graf 2: Porovnanie miery oblúbenosti a neoblúbenosti jednotlivých predmetov

Navyše, ak porovnávame parciálne koeficienty oblúbenosti s parciálnymi koeficientmi neoblúbenosti, v prípade matematiky, fyziky a chémie parciálne koeficienty neobl'úbenosti dosahujú výrazne vyššie hodnoty ( $v$ absolútnej hodnote) ako parciálne koeficienty oblúbenosti (u ostatných predmetov tieto rozdiely nie sú také výrazné). $\mathrm{Na}$ druhú stranu však informatiku a programovanie ako predmety technického charakteru možno zaradit' do skupiny prírodovedne orientovaných predmetov a pritom v získanej hierarchii oblúbenosti predmetov sú na popredných miestach, informatika dokonca získala úplne najvyšší globálny koeficient oblúbenosti. V tomto kontexte by sme dokonca proti tvrdeniu o odmietavých postojoch mládeže voči prírodovedným predmetom mohli vyslovit' námietku, založenú na argumente, že medzi najoblúbenejšie predmety u mládeže dominantne patrí práve (technická prírodovedná disciplína) informatika a v podstate aj programovanie. Na tomto mieste 
však treba upozornit' na limitované možnosti zovšeobecňovania získaných výsledkov vzhl'adom na rozsah výskumnej vzorky a vzhl'adom na orientáciu respondentov zapojených do výskumu - študijné zameranie jednej časti respondentov na cudzie jazyky a druhej časti respondentov na informatiku a programovanie. Domnievame sa, že práve táto skutočnost' sa výraznou mierou podiel'a na výsledných hodnotách dosiahnutých pre parciálny koeficient oblúbenosti a neoblúbenosti predmetu programovanie.

\section{Výsledky hodnotenia sledovaných komponentov vyučovania informatiky a programovania zo strany študentov}

Výsledky analýzy sledovaných motivačných faktorov pre celý výskumný súbor študentov bez diferenciácie na ich študijné zameranie uvádzame v tabul'ke 2. Okrem toho pre predmet informatika uvádzame aj výsledky vyhodnotené zvlášt’ pre podskupinu študentov so zameraním na výučbu informatiky a programovania a podskupinu študentov so zameraním na výučbu cudzích jazykov (tabul'ka 3).

\begin{tabular}{|l|c|c|c|c|c|c|}
\hline Predmet & \multicolumn{3}{|c|}{ INFORMATIKA } & \multicolumn{3}{c|}{ PROGRAMOVANIE } \\
\hline Faktor & $\begin{array}{c}\text { Koeficient } \\
\text { celkového } \\
\text { hodnotenia }\end{array}$ & $\begin{array}{c}\text { Koeficient } \\
\text { pozitívneho } \\
\text { hodnotenia }\end{array}$ & $\begin{array}{c}\text { Koeficient } \\
\text { negatívneho } \\
\text { hodnotenia }\end{array}$ & $\begin{array}{c}\text { Koeficient } \\
\text { celkového } \\
\text { hodnotenia }\end{array}$ & $\begin{array}{c}\text { Koeficient } \\
\text { pozitívneho } \\
\text { hodnotenia }\end{array}$ & $\begin{array}{c}\text { Koeficient } \\
\text { negatívneho } \\
\text { hodnotenia }\end{array}$ \\
\hline $\begin{array}{l}\text { Zaujímavost' } \\
\text { obsahu učiva }\end{array}$ & 1,47 & 1,98 & $-1,50$ & 0,90 & 2,12 & $-1,43$ \\
\hline $\begin{array}{l}\text { Zaujímavost' } \\
\text { riešenia úloh }\end{array}$ & 0,81 & 1,98 & $-1,73$ & 0,78 & 1,66 & $-2,05$ \\
\hline $\begin{array}{l}\text { Spôsob prezentácie } \\
\text { učiva učitel’om }\end{array}$ & 0,95 & 2,01 & $-1,78$ & 0,69 & 2,13 & $-2,15$ \\
\hline $\begin{array}{l}\text { Zaujímavost' } \\
\text { učebných pomôcok }\end{array}$ & 1,57 & 2,19 & $-1,63$ & 1,27 & 2,13 & $-1,83$ \\
\hline $\begin{array}{l}\text { Využ. poznatkov pre } \\
\text { vlastnú budúcnost' }\end{array}$ & 1,50 & 2,71 & $-1,31$ & 1,00 & 2,40 & $-1,88$ \\
\hline $\begin{array}{l}\text { Využ. poznatkov pri } \\
\text { riešení praktických } \\
\text { úloh }\end{array}$ & 2,06 & 2,31 & $-1,16$ & 1,50 & 2,34 & $-1,50$ \\
\hline
\end{tabular}

Tabul'ka 2: Vyhodnotenie sily sledovaných faktorov pre predmet informatika a programovanie

\begin{tabular}{|l|c|c|c|c|c|c|}
\hline \multirow{2}{*}{ INFORMATIKA } & \multicolumn{2}{|c|}{$\begin{array}{c}\text { Koeficient } \\
\text { celkového } \\
\text { hodnotenia }\end{array}$} & \multicolumn{2}{c|}{$\begin{array}{c}\text { Koeficient } \\
\text { pozitívneho } \\
\text { hodnotenia }\end{array}$} & \multicolumn{2}{c|}{$\begin{array}{c}\text { Koeficient } \\
\text { negatívneho } \\
\text { hodnotenia }\end{array}$} \\
\hline Faktor & PC & CJ & PC & CJ & PC & CJ \\
\hline $\begin{array}{l}\text { Zaujímavost' } \\
\text { obsahu učiva }\end{array}$ & 1,52 & 1,37 & 2,13 & 1,70 & $-1,55$ & $-1,33$ \\
\hline $\begin{array}{l}\text { Zaujímavost' } \\
\text { riešenia úloh }\end{array}$ & 1,1 & 0,59 & 2,04 & 1,82 & $-1,92$ & $-1,50$ \\
\hline $\begin{array}{l}\text { Spôsob prezentácie učiva } \\
\text { učitel'om }\end{array}$ & 1 & 0,85 & 2,1 & 1,84 & $-1,93$ & $-1,50$ \\
\hline Zaujímavost' učebných pomôcok & 1,52 & 1,44 & 2,15 & 1,83 & $-1,62$ & $-1,60$ \\
\hline $\begin{array}{l}\text { Využ. poznatkov pre vlastnú } \\
\text { budúcnost' }\end{array}$ & 1,78 & 0,92 & 2,36 & 2,29 & $-1,22$ & $-1,40$ \\
\hline $\begin{array}{l}\text { Využ. poznatkov pri riešení } \\
\text { praktických úloh }\end{array}$ & 2,2 & 1,77 & 2,4 & 2,12 & $-1,33$ & $-1,00$ \\
\hline
\end{tabular}

Tabul'ka 3: Vyhodnotenie sily jednotlivých faktorov vyučovania predmetu informatika separátne pre skupiny respondentov so študijným zameraním na informatiku a programovanie (PC) a na cudzie jazyky (CJ)

Porovnanie motivačnej sily sledovaných faktorov vyjadrenej koeficientom ich celkového hodnotenia pre obidva predmety je znázornené na grafe 3. Na porovnanie mieru ich pozitívneho a negatívneho hodnotenia prezentujeme v grafoch 4 a 5 . 


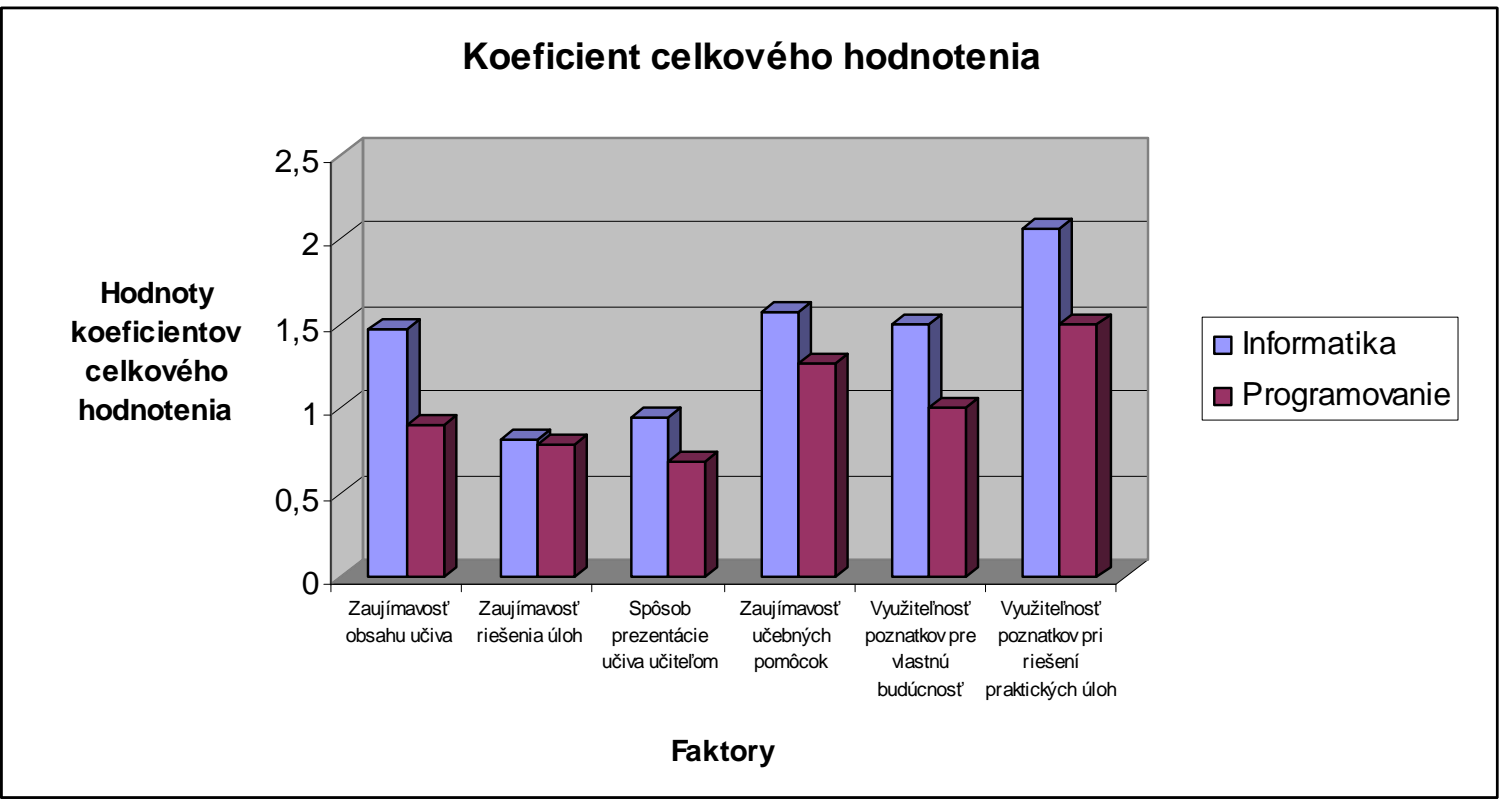

Graf 3: Vel'kost' motivačnej sily sledovaných faktorov pre predmety informatika a programovanie

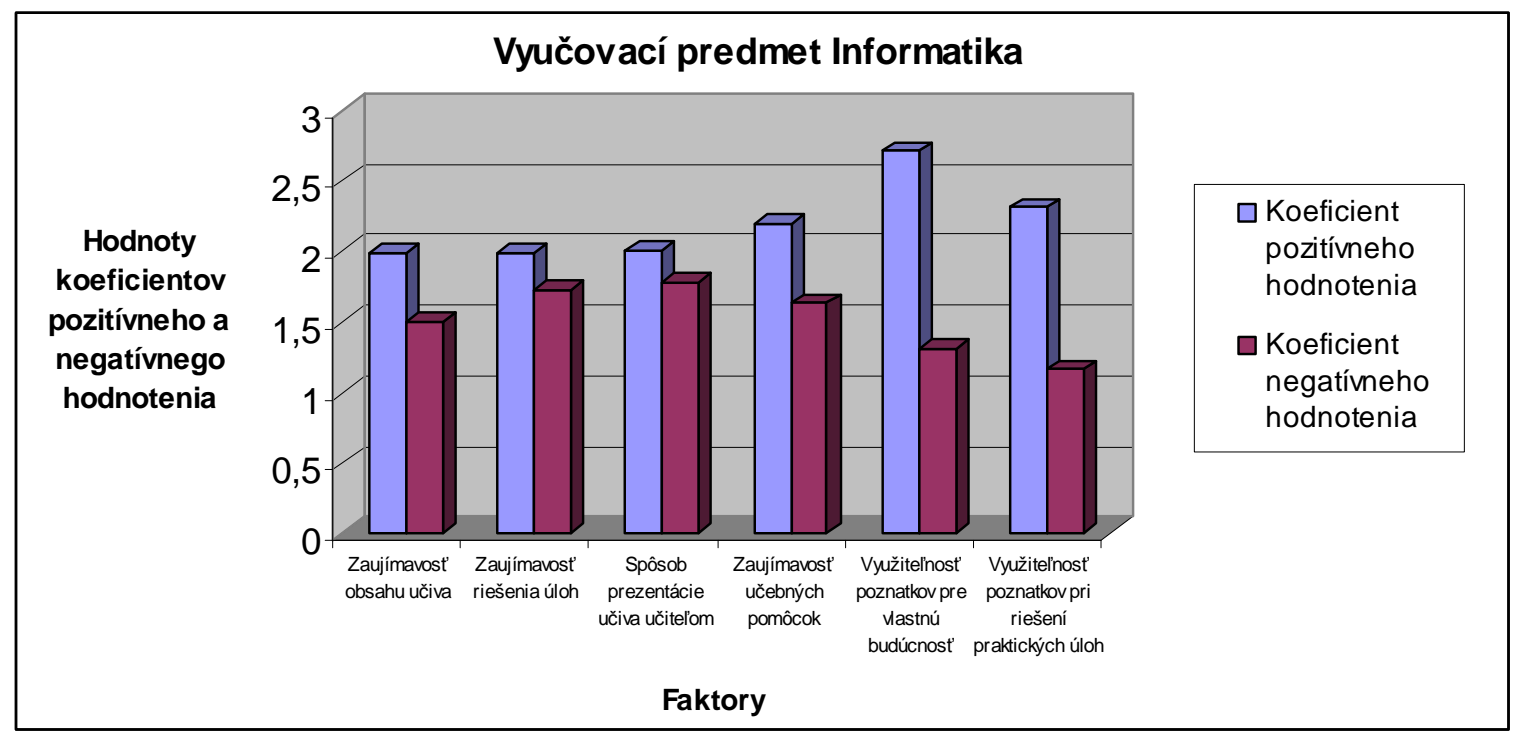

Graf 4: Porovnanie hodnôt koeficientov pozitívneho a negatívneho hodnotenia sledovaných faktorov pre predmet informatika

$\mathrm{Na}$ základe koeficientov celkového hodnotenia možno v prípade informatiky aj programovania konštatovat' zhodu motivačnej sily jednotlivých sledovaných motivačných faktorov. Ako najvýznamnejší motivačný faktor sa prejavuje uvedomovanie si využitel'nosti nadobúdaných poznatkov pri riešení praktických úloh. Pre tento faktor koeficient celkového hodnotenia nadobúda signifikantne najvyššiu hodnotu $\mathrm{v}$ oboch prípadoch $(2,06$ a 1,50$)$. V spojitosti s hodnotením motivačného faktora využitel'nosti nadobúdaných poznatkov pri riešení praktických úloh zaujímavým zistením je, že využitel'nost' osvojovaných poznatkov pre vlastnú budúcnost' sa umiestnila až za motivačným faktorom zaujímavosti učebných pomôcok používaných vo vyučovacom procese. $\mathrm{Na}$ tomto mieste by mohli byt' vznesené dve námietky voči diskutovaným výsledkom. Jednou je námietka signifikantnosti rozdielov medzi hodnotami koeficientov celkového hodnotenia uvedených motivačných faktorov. 


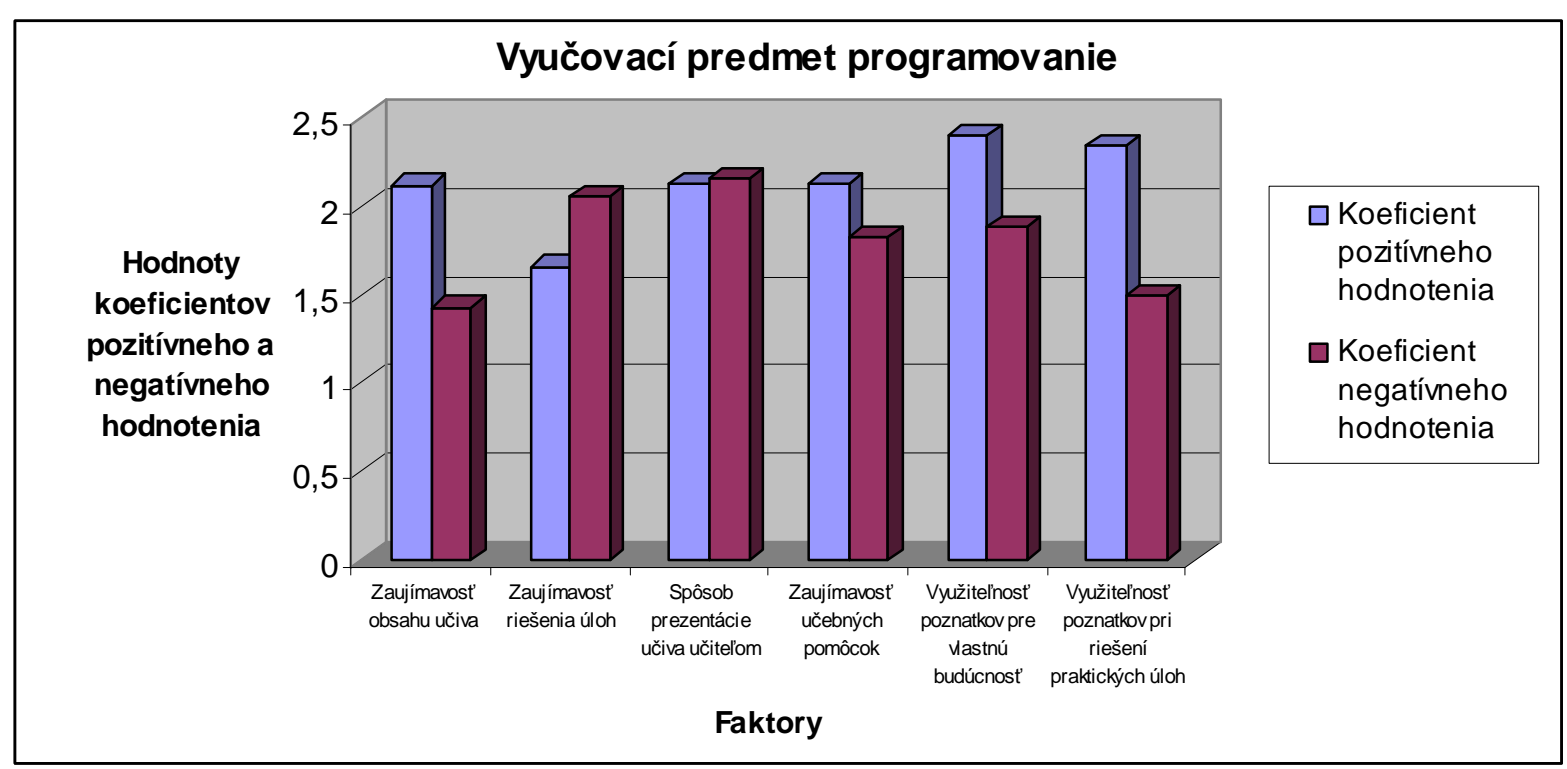

Graf 5: Porovnanie hodnôt koef. poz. a neg. hodnotenia sledovaných faktorov (predmet programovanie)

Táto je oprávnená v prípade vyučovacieho predmetu informatika, nie však v prípade vyučovacieho predmetu programovanie. V prípade vyučovacieho predmetu programovanie sa zaujímavost' používaných učebných pomôcok prejavuje signifikantne ako silnejší motivačný faktor než využitel'nost' osvojovaných poznatkov pre vlastnú budúcnost' $(1,27$ a 1,00). Tento fakt je pozoruhodný hlavne v súvislosti s druhou možnou námietkou, ktorou je otázka korektnosti porovnávania získaných hierarchií sledovaných motivačných faktorov pre vyučovacie predmety informatika a programovanie, nakol'ko tieto hierarchie boli odvodené pre nerovnocenné výskumné vzorky respondentov. Kým v jednom prípade (predmet informatika) medzi respondentmi boli okrem študentov špecializujúcich sa vo svojom štúdiu na informatiku a programovanie aj študenti orientujúci sa na štúdium cudzích jazykov, $\mathrm{v}$ druhom prípade (predmet programovanie) motivačnú silu jednotlivých faktorov hodnotili len študenti špecializujúci sa na informatiku a programovanie (študenti so zameraním na výučbu cudzích jazykov nemajú programovanie v učebných osnovách). Je preto vysoko pravdepodobné, že čast' respondentov zo skupiny študentov špecializujúcich sa na štúdium cudzích jazykov pri posudzovaní významu predložených položiek pre ich osobu samotný predmet informatika priamo nespája so svojou profesionálnou budúcnost'ou. Avšak vzhl'adom na vysoké skóre výsledného celkového hodnotenia $(1,50)$ je zrejmé, že aj títo študenti považujú poznatky nadobúdané v rámci predmetu informatika pre svoje budúce fungovanie $v$ rámci spoločnosti za potrebné a užitočné, nakol'ko sa neustále zintenzívňuje prienik informačných a komunikačných technológií do všetkých sfér spoločnosti a oblastí hospodárstva. Napriek tomu je však značný rozdiel $v$ hodnotení tejto položky skupinou študentov so zameraním na informatiku a programovanie $(1,78)$ a skupinou študentov so zameraním na cudzie jazyky $(0,92)$. Ak študijné zameranie časti respondentov posudzujúcich motivačné faktory predmetu informatika mohlo ovplyvnit' ich hodnotenie jednotlivých faktorov, pri posudzovaní motivačných faktorov predmetu programovanie tento atribút nezohráva žiadnu rolu, nakol'ko v tomto prípade sa vyjadrovali len študenti navštevujúci triedy so zameraním na informatiku a programovanie. Ak si uvedomíme toto rozdielne pozadie respondentov, môžeme ako prekvapujúci výsledok označit' skutočnost', že $v$ prípade predmetu informatika pre „,v̌̌eobecnejšiu“ vzorku respondentov zaujímavost' učebných pomôcok a využitel'nost' nadobúdaných poznatkov pre vlastnú budúcnost' sú rovnako silné motivačné faktory (1,57 1,50), kým v prípade predmetu programovanie pre „počítačovo“ orientovanú vzorku respondentov zaujímavost' učebných pomôcok signifikantne prevýšila význam využitel'nosti nadobúdaných poznatkov pre vlastnú (osobnú/prefesionálnu) budúcnost' (1,27 a 1,00).

Charakteristickou črtou hodnotenia všetkých troch vyššie diskutovaných motivačných faktorov, t.j. využitel'nosti poznatkov pri riešení praktických úloh, využitel'nosti poznatkov pre 
vlastnú budúcnost' a zaujímavosti učebných pomôcok, rovnako pre informatiku ako aj pre programovanie je, že koeficienty ich pozitívneho hodnotenia sú signifikantne vyššie ako koeficienty ich negatívneho hodnotenia (v prípade informatiky $2,31: 1,16 ; 2,71: 1,31$; $2,19: 1,63$ a v prípade programovania $2,34:$ $1,50 ; 2,40: 1,88 ; 2,13: 1,83)$, čo hodnotíme vel'mi pozitívne. Analogické konštatovanie možno uviest' aj pre motivačný faktor zaujímavosti obsahu preberaného učiva (informatika 1,98:1,50; programovanie 2,12 : 1,43). Celkovo však tento faktor vykazuje výrazne nižšiu motivačnú silu a to hlavne v prípade predmetu programovanie $(0,90)$.

Na prvý pohlad sa ako vel'mi negatívny výsledok môžu zdat' vel'mi nízke hodnoty, ktoré dosiahli koeficienty celkového hodnotenia spôsobu prezentácie preberaného učiva vyučujúcimi $(0,95$ a 0,69$)$ a zaujímavosti riešených úloh $(0,81$ a 0,78$)$. Tieto hodnoty v rámci celkových výsledkov môžu zvádzat' $\mathrm{k}$ tvrdeniam o nedostatočnej pedagogickej erudícii vyučujúcich, nižšej kvalite vyučovania, resp. určitých nedostatkoch vo vyučovaní ako informatiky tak aj programovania. S takýmito unáhlenými závermi však rozhodne nemôžeme súhlasit'. Argumentmi, ktoré ich vyvracajú, sú hodnoty koeficientov pozitívneho hodnotenia. Hodnota koeficienta pozitívneho hodnotenia spôsobu prezentácie preberaného učiva vyučujúcim v prípade predmetu informatika je 2, 01 a v prípade predmetu programovanie 2,13. Tieto hodnoty potvrdzujú erudovanost' pedagógov a náležitú kvalitu nimi odvádzaného vyučovacieho procesu. Problém je podl'a všetkého $v$ určitom a priorne negatívnom odmietavom postoji u tých študentov, ktorí nepovažujú preberané učivo v súvislosti so svojou osobou za prakticky upotrebitel'né. T.j. tí študenti, ktorí hodnotia využitel'nost' preberaných poznatkov pri riešení praktických úloh a pre vlastnú budúcnost' negatívne, postrádajú vnútornú motiváciu $\mathrm{k}$ učeniu a vel'akrát sa automaticky štylizujú do pozície znudeného recipienta alebo recipienta, na ktorého sú kladené neúmerné požiadavky.

\section{Záver}

$\mathrm{Na}$ základe prezentovaných výsledkov môžeme konštatovat', že informatika a programovanie ako technické predmety na rozdiel od prírodovedných predmetov chémia a fyzika nepatria $\mathrm{v}$ súčasnosti $\mathrm{k}$ predmetom, $\mathrm{ku}$ ktorým by mládež zaujímala negatívne odmietavé postoje. $\mathrm{Aj} \mathrm{v}$ ich prípade však podobne ako $\mathrm{v}$ prípade prírodovedných predmetov platí, že najvýraznejším motivačným faktorom pre osvojovanie si príslušných poznatkov je uvedomovanie si zmysluplnosti a upotrebitel'nosti nadobúdaných poznatkov a možností ich využitia či už pre vlastnú sebarealizáciu alebo pre prax. Naše zistenia môžeme dat' do paralely aj so zisteniami Štátnej školskej inšpekcie, ktorá na základe komplexných inšpekcií vykonaných v 31 gymnáziách SR vo svojej správe o stave výchovy a vzdelávania v gymnáziách v školskom roku 2007/2008 konštatovala, že nie na všetkých hodinách sa dosahuje požadovaná úroveň praktickej aplikácie teoretických poznatkov a napriek dobrej pracovnej atmosfére a efektívnemu využívaniu učebných pomôcok kvalita vyučovania je často znižovaná nedostatočnou motiváciou študentov (Správa o stave a úrovni..., 2008).

\section{Literatúra}

(1) BURGEROVÁ, J. Nové technológie vo výučbe. Prešov, 2003. ISBN 80-968897-1-0

(2) NAGY, T. - KUBIATKO, M. NAGYOVÁ, S. Postoje žiakov v spojitosti s prípravou učitel'ov $v$ problematike implementácie IKT do vyučovacieho procesu. Informatika $v$ škole 33/34, 2008, s. 20 - 24. ISSN 1335-616X

URL: http://www.uips.sk/sub/uips.sk/images /JE/cas informatika/infor33 34\%202008.pdf

[cit. 12/11/2008]

(3) Správa o stave a úrovni pedagogického riadenia, procesu a podmienok výchovy a vzdelávania $\mathrm{v}$ gymnáziách $\mathrm{v}$ SR v školskom roku 2007/2008 URL: http://sss.ssiba.sk/ dokumenty/cinnosti/20072008/str0708/str0708. pdf [cit. 27/11/2008]

(4) ŠEBEŇ, V. - JAKUBOV, R. Motivácia činnosti žiakov vo vyučovaní fyzika na ZŠ. Acta Didactica 2, s. 71 - 81. Nitra, FPV UKF, 1997

(5) ZÁHOREC, J.: Elektronické výučbové prostriedky $\quad \mathrm{v}$ technológii vzdelávania. Dizertačná práca. Nitra, PF UKF, 2008

Prof. PaedDr. Alena Hašková, CSc.

PaedDr. Ján Záhorec, PhD.

Ústav technológie vzdelávania, Pedagogická

fakulta Univerzity Konštantína Filozofa,

Dražovská cesta 4, 94974 Nitra, SK

e-mail: ahaskova@ukf.sk,jzahorec@ukf.sk 